\title{
Smoking Behavior
}

National Cancer Institute

\section{Source}

National Cancer Institute. Smoking Behavior. NCI Thesaurus. Code C20134.

Any of the activities associated with tobacco smoking. 